\title{
ESTIMATION OF INBREEDING RATES AND EXTINCTIONRISK OF FORTY ONE BELGIAN CHICKEN BREEDS IN 2005 AND 2010
}

\author{
ESTIMACIÓN DE TASA DE CONSANGUINIDAD Y RIESGO DE EXTINCIÓN EN \\ CUARENTA Y UNA RAZAS BELGAS DE POLLOS EN 2005 Y 2010
}

\author{
Moula, N. ${ }^{1}$; Philippe, F.X. ${ }^{1}$; Antoine-Moussiaux, N. ${ }^{1}$, Leroy, P. ${ }^{1 *}$ and Michaux, C. ${ }^{1}$ \\ 'Département des Productions Animales. Service de Génétique Quantitative. Faculté de Médecine \\ Vétérinaire. Université de Liège. Liège. Belgique. *Pascal.Leroy@ulg.ac.be
}

AdDiTIONAL KEYWORDS

Biodiversity. Conservation. Local chicken breed.

\section{SUMMARY}

In Belgium, as generally in Europe, the dominant position of the high producing commercial strains specialized in meat or eggs production threats of extinction the local traditional breeds. In this work, a follow up of the changes in populations size, and the rates of inbreeding of the Belgian poultry breeds, has been carried out in 2005 and 2010 . About forty breeds were concerned. The Belgian hen breeds being overwhelmingly under threat of extinction, because of the low number of individuals by breed. For each of these breeds, various criteria were considered, risk status, breeding male to breeding female ratio, effective population size, effective population size to actual size ratio and rate of inbreeding.

\section{RESUMEN}

En Bélgica, y generalmente en Europa, la posición dominante de estirpes comerciales altamente productivas, especializadas en la producción de carne o huevos, amenaza de extinción a las razas locales tradicionales. Se ha realizado, en 2005 y 2010, un seguimiento de las tasas de consanguinidad de razas de gallinas belgas. Unas cuarenta razas han sido consideradas. Las razas belgas de gallinas se encuentran abrumadoramente en peligro de extinción a causa del escaso número de individuos en cada raza. Para cada una de las razas fueron considerados varios criterios: estado de riesgo, relación reproductores machos/reproductores hembra, tamaño efectivo de población, relación tamaño efectivo/tamaño actual y tasa de consanguinidad.

Recibido: 29-7-13. Aceptado: 28-1-14.

\section{Palabras clave adicionales}

Biodiversidad. Conservación. Razas locales aves.

\section{INTRODUCTION}

The conservation of animal genetic resources is capital for the sustainable development of the poultry production. However, a gradual and relentless depleting of available breeds is now rife at the scale of the planet.

The extreme specialization of some breeds and their dissemination across the world, have taken place at the expense of local breeds which are less profitable. Infectious diseases and epidemics, natural disasters and other conflicts also threaten these resources.

Traditional poultry breeds contribute significantly to meat and egg production, they represent more than $80 \%$ of the world production (Besbes, 2009). However, most of these breeds have not been studied by the scientific community. According to the FAO, about $40 \%$ of the avian breeds are not inventoried (Besbes, 2009). Important efforts are therefore necessary to evaluate the situation of these breeds. The efficient management of any animal genetic resources requires the identification of the concerned breeds, their risk status, the estimation of their phenotypic and genetic variations and the identification of peculiarities if any.

Belgium has a unique avian genetic capital with forty breeds and many hundreds of varieties (Moula, 2012).

Arch. Zootec. 63 (242): 389-392. 2014. 


\section{MOULA, PHILIPPE, ANTOINE-MOUSSIAUX, LEROY AND MICHAUX}

The present study aims to evaluate the risk status and the inbreeding rate of the Belgian traditional chicken breeds populations bred by small-scale traditional farms, fanciers and research institutions.

\section{MATERIAL AND METHODS}

The data collected in 2005 by Larivière and Leroy (2007) and in 2010 by the Belgian National Federation of Farmyard Animal Breeders and by the Faculty of Veterinary Medicine, University of Liege, consisted of the number of breeding males $(\mathrm{Nm})$ and breeding females $(\mathrm{Nf})$ for each traditional Belgian chicken breed in traditional flocks, farm-parks and research centers.

The risk status risk categorization was based on the criteria of the FAO (2007). Endangered: female 100-1000, male 5-20. Critical: female $<100$, male $<5$.

The effective population size $(\mathrm{Ne})$ is the number of individuals of an ideal population that would give rise to the same inbreeding rate observed in the actual population. Calculations are based on the formula (Wright, 1931):

$$
\mathrm{Ne}=4 \mathrm{~N}_{\mathrm{f}} \mathrm{N}_{\mathrm{m}} / \mathrm{N}_{\mathrm{f}}+\mathrm{N}_{\mathrm{m}}
$$

where:

$\mathrm{Nf}=$ the number of breeding females; $\mathrm{Nm}=$ the number of breeding males.

Inbreeding rate $(\Delta \mathrm{F})$ per generation was calculated for the 41 traditional chicken breed's populations using the formula (Wright, 1931):

$$
\Delta \mathrm{F}=1 / 2 \mathrm{~N}_{\mathrm{e}}
$$

\section{RESULTSANDDISCUSSION}

A total of 41 chicken breeds were listed in 2005 and 40 in 2010 (table I). In 2005, the total number of individuals censored was 10220 (small size breeds: 4903, standard size breeds: 5317 individuals). In 2010, the overall number decreased to 9592 individuals (small size breeds: 4892 , standard size breeds: 4700 individuals).

As mentioned in table I, in 2005, 14 Belgian chicken breeds were endangered, 25 were in critical situation and two breeds (Malines and Barbu d'Anvers) were not at risk. In 2010, 16 breeds were endangered $(40 \%), 23$ in critical situation $(57.5 \%)$ and only one breed (Ardennaise) was not at risk. The genetic erosion hitting the Belgian chicken breeds continues to increase. In 5 years (2005-2010), the proportion of breeds in endangered or critical status increases from 95.12 to $97.56 \%$.

As mentioned in the table $\mathbf{I}$, the population size of 21 breeds increased in 2010 compared to 2005 , but 18 breeds knew a decline in their effectives.

In 2005, the actual population of Ardennaise was 682 (table I). However, in 2010 due to the repopulation campaigns of the small farms carried by the University of Liege from its own stocks, this value reached more than 1850 individuals (Moula, 2012).

One endangered breed in 2005 improved its situation in 2010, the Ardennaise one and 4 saw their situation to deteriorate among which the Barbu d'Anvers from not at risk to endangered. Among the critical breeds in 2005, three passed from stage critical to endangered in 2010 and one probably was extinct, the Bleue de Lasnes.

A large variation of $\mathrm{Ne}$ is recorded in the Belgian chicken breeds. The highest $\mathrm{Ne}$ value in 2005 was recorded for Malines breed (1465) and the lowest one for Zingem chair chicken breed (2). In 2010, the Ardennaise (1598) and the Zingem chair (6) recorded the highest and the lowest $\mathrm{Ne}$ values respectively. The $\mathrm{Ne} / \mathrm{N}$ and $\mathrm{Nm} / \mathrm{Nf}$ ratios varied from 57 to $98 \%$ and from 21 to $73 \%$ respectively in 2005 and from 73 to $93 \%$ and from 30 to $57 \%$ in 2010.

The estimated inbreeding rates $\Delta \mathrm{F}$ varied from 0.03 to $5.6 \%$ per generation in 2005 . In 2010 , these ratios ranged from 0.03 to $8.75 \%$ per generation (table I).

In a sample of 37 European local breeds, 


\section{INBREEDING RATES AND EXTINCTION RISK OF SOME BELGIAN CHICKEN BREEDS}

Table I. Data of Belgian chicken breeds. (Datos de razas aviares belgas).

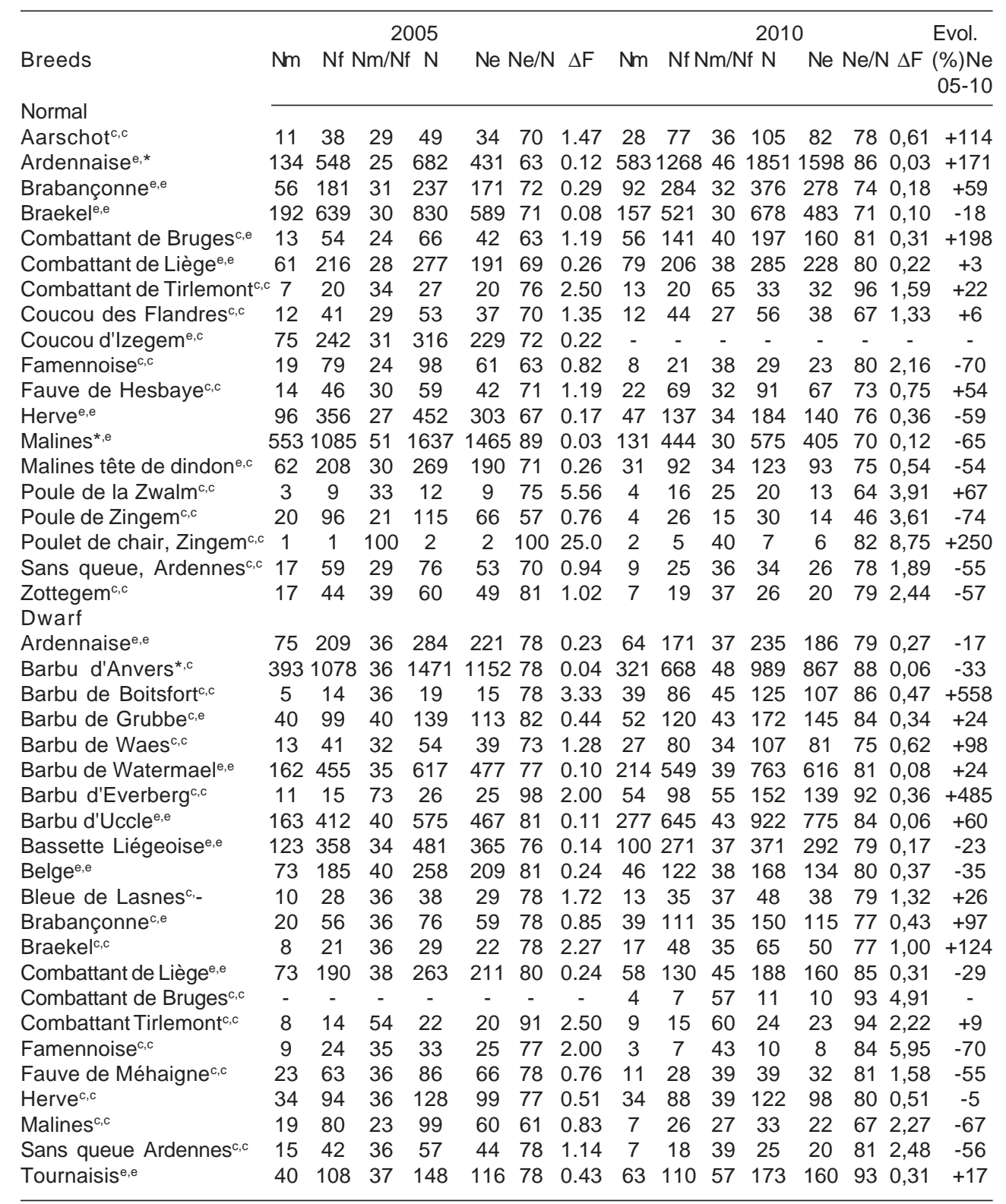

Number of breeding males $(\mathrm{Nm})$ and females $(\mathrm{Nf}) ; \mathrm{Nm} / \mathrm{Nf}$ : male:female ratio; $\mathrm{N}$ : total breeding population; $\mathrm{Ne}$ e effective population size; $\mathrm{Ne} / \mathrm{N}$ : ratio of breeders contributing efficiently genes (\%); $\Delta \mathrm{F}$ hypothetical rates of inbreeding per generation (\%).

c,erisk status: c= critical; e= endangered; letter before comma: 2005, after comma: 2010. *not at risk. 


\section{MOULA, PHILIPPE, ANTOINE-MOUSSIAUX, LEROY AND MICHAUX}

Spanola et al. (2007) estimated $\mathrm{Ne}$ and $\Delta \mathrm{F}$. The actual size of these populations varied from 2800 to $170, \mathrm{Ne}$ from 2285 to $70, \mathrm{Ne} / \mathrm{N}$ from 82 to $42 \%, \mathrm{Nm} / \mathrm{Nf}$ from 40 to $13 \%$ and $\Delta \mathrm{F}$ from 2 to $71 \%$. The comparison of these values to those obtained in a subsample of 24 of the Belgian breeds with Ne values between 1598 and 67 in 2010, showed similar $\Delta \mathrm{F}$ from 3 to $75 \%$ but higher.

With a fitness depression of $1 \%$ of inbreeding and in the absence of correlated response to artificial selection, the critical $\mathrm{Ne}$ for which the fitness due to natural selection against deleterious mutation balance the fitness decrease due to inbreeding depression, varies from 30 to 250 owing to the variation and to the heritability of the fitness (Meuwissen and Woolliams, 1994). Using de rules of these latter authors, in adverse conditions (coefficient of variation and heritability of fitness equal to 0.02 and 0.05 respectively), 8 Belgian breeds could maintain their fitness and in favorable conditions (coefficient of variation and heritability of fitness equal to 0.04 and 0.10 respectively), 29 Belgian breeds could

\section{REFERENCES}

Besbes, B. 2009. Genotype evaluation and breeding of poultry for performance under sub-optimal village conditions. World Poultry Sci J, 65: 260-271.

FAO. 2007. The State of the World's Animal Genetic Resources for Food and Agriculture. Edited by B. Rischkowsky and D. Pilling. Rome. 511 pp.

Larivière, J.M. and Leroy, P. 2007. Status and conservation of native poultry breeds in Belgium. Ann Anim Sci, 1 (Suppl): 87-91.

Lynch, M.; Conery, J. and Burger, R. 1995. Mutation accumulation and the extinction of small populations. Am Nat, 146: 489-518.

Meuwissen, T.H.E. and Woolliams, J. 1994. Effective sizes of livestock populations to prevent a maintain their fitness. From a genetic point of view, Lynch et al. (1995), concluded that a population with effective size smaller than 100 and therefore with an actual size smaller than 1000 , is highly vulnerable to extinction into a hundred of generations due to mutation accumulation. But pointing out other threats due demographic and environmental factors they found inadequate the usual threshold of 100 to 1000 individuals defining endangered population.

In Belgium, as generally in Europe, the commercial strains dominate the production of meat and eggs. Local breeds in turn, are held almost exclusively by hobbyist breeders and fanciers. Most of Belgian chicken breeds have very small numbers and are threaten of extinction (table I). It is therefore necessary to implement an efficient management of the reproduction, such as limiting the $\mathrm{Nm} / \mathrm{Nf}$ ratio to $25 \%$ or exchanging breeding stocks among flocks, ensuring both a high level of fertility and a low rate of inbreeding. The conservation of the biodiversity in general and of the poultry breeds in particular is a common interest and need public aids.

decline in fitness. Theor Appl Genet, 89: 10191026.

Moula, N. 2012. Biodiversité avicole dans les pays industrialisés et en développement: caractérisation et étude des performances de production de races gallines locales. Thesis, Université de Liège. Liège, Belgique. 257 pp.

Spalona, A.; Ranvig, H.; Cywa-Benko, K.; Zanon, A.; Sabbioni, A.; Szalay, I.; Benkova, J.; Baumgartner, J. and Szwaczkowski, T. 2007. Population size in conservation of local chicken breeds in chosen European countries. Arch Geflügelk, 71: 49-55.

Wright, S. 1931. Evolution in mendelian populations. Genetics, 16: 97-159. 